\author{
Judyta Ewa Perczak \\ Uniwersytet Jana Kochanowskiego w Kielcach \\ ORCID: 0000-0002-4759-4024
}

\title{
Polish socialist advertising in 1945-1989: Status and sources of and outlooks for the research
}

\begin{abstract}
The widespread conviction that commercial advertisements neither existed nor were actually needed in Poland under socialist rule is quite untrue. Admittedly, they were not identical to Western advertisements of the time or today's advertising activities, but they fulfilled all advertising functions and were a tool regulating the market that was always poor, creating the socialist consumption model as well as educating people so as to make them implement the said model. The advertising activity in question followed capitalist models as far as possible, but it worked out its own forms, means of expression and theory included in many books and specialist magazines, too. The analysis of the advancement of research on advertising in the PRP, sources being the basis that research and its desired directions is the goal of this article. The study questions asked are: 1 . What kind of source documents can studies of advertising in the PRP be based on? 2. What is the current advancement of research on the history of advertising in Poland before 1945? What is the current advancement of research on advertising in the PRP? Which areas of science could use the source documents underlying the research on advertising in the PRP? This article is based on the analysis of various groups of source documents, particularly specialist and scientific literature from the 1945-1989 period, scientific papers on socialist advertising published after 1989 and archival records. This article is an analysis of status of research on advertising dr Judyta Ewa Perczak 128 in the People's Republic of Poland (PRP), sources used in the said research and directions that it should take. The abundance of sources is pointed out. The said sources are mainly archival ones available from the Archives of New Records in Warsaw (they include, among other things, 'Rada Programowa Reklamy' (Advertising Program Council), a file being a part of the 'Ministerstwo Handlu Weunętrznego' (Ministry of Internal Trade) unit; the 'Ministerstwo Handlu Zagranicznego' (Ministry of Foreign Trade) unit including files with information about Agpol, a foreign trade business in charge of advertising on international markets; 'Przedsiębiorstwo Usług Reklamowych „Reklama” w Warszawie, Państwowa Agencja Reklamowa „Reklama” 1971-2004', records of the Political Bureau of the Central Committee of the Polish United Workers' Party, those of the Supreme Chamber of Control and many other); the Documentation Department of TVP S.A. and the archives of Polskie Radio S.A. Films, printed matter and advertisements themselves being invaluable research material are also referred to. Keywords: advertising, history of advertising, sources of advertising, socialism, People's Republic of Poland.
\end{abstract}




\section{Polska reklama socjalistyczna w latach 1945-1989. Stan, źródła i perspektywy badań}

\section{Streszczenie}

Potoczny pogląd o braku reklamy w Polsce Ludowej i braku potrzeby jej stosowania jest całkowicie niepraudziuy. Nie była upraudzie tożsama z óuczesną reklamą zachodnią czy z działalnością znaną nam obecnie, ale spełniała uszystkie przypisywane reklamie funkcje, będąc róunocześnie narzędziem regulacji zausze ubogiego rynku, kreacji socjalistycznego modelu konsumpcji oraz edukacji i wychowania obywateli, by ten model realizowali. Czerpiąc u miarę możliwości z wzorców kapitalistycznych, uytworzyła jednocześnie własne formy, środki wyrazu, a także teorię zawartą w licznych publikacjach książkowych i prasie fachowej.

Celem artykułu jest analiza stanu badań nad reklamą w PRL, źródeł do tych badań i kierunków, w których należy je prowadzić. Postawione pytania badaucze to: 1 . Jakie źródła można uykorzystać w badaniu reklamy u PRL? 2. Jaki jest aktualny stan badań nad historią reklamy w Polsce sprzed 1945 roku? 3. Jaki jest stan badań nad reklamą w PRL? 4. W jakich dziedzinach wiedzy można uykorzystać źródła do badań nad reklamą w PRL? Artykuł opiera się na analizie różnych grup źródeł, ze szczególnym uwzględnieniem literatury fachowej i naukowej z lat 1945-1989, prac naukowych poświęconych reklamie socjalistycznej, opublikowanych po 1989 roku oraz archiwaliów. Zwrócono uwagę na bogactuo źródeł, szczególnie archiwalnych, udostępnianych w Archiwum Akt Nowych w Warszawie (m.in. zbiór Rada Programowa Reklamy, stanowiący część zespołu Ministerstwo Handlu Wewnętrznego, zespół Ministerstwo Handlu Zagranicznego, gdzie znajdują się teczki z informacjami o Przedsiębiorstwie Handlu Zagranicznego „Agpol”, zajmującym się reklamą na rynkach zagranicznych, Przedsiębiorstwo Usług reklamowych „Reklama” w Warszawie, Państwowa Agencja Reklamowa „Reklama” 1971-2004, akta Biura Politycznego KC PZPR, Najwyższej Izby Kontroli i in.), Oddziale Dokumentacji Aktowej TVP S.A. i archiuum Polskiego Radia S.A. Wymieniono też źródła filmowe, drukowane oraz same reklamy, które także są nieocenionym materiałem do badań. Na podstawie analizy źródeł dokonano omówienia pól badawczych, w których zagadnienia związane z reklamą mogą stać się nieocenionym uzupełnieniem stanu wiedzy.

Słowa kluczowe: reklama, historia reklamy, źródła do reklamy, socjalizm, Polska Rzeczpospolita Ludowa.

\section{Introduction}

This article discusses the current status of research on the Polish advertising from the 1945-1989 period, analyses source documents and points out opportunities available to researchers (communication science, history of culture, history of economics and many other specialists) exploring this topic. The conviction that drawing upon the wealth of varied source documents underlying the history of socialist advertising will contribute to development of our knowledge of the economic, social and cultural aspects of life in the People's Republic of Poland is the reason why this article has been written. As socialist advertising was developed under unusual economic and political conditions, in comparison with Western advertising of the time and the advertising we see in today's Poland. This article is an attempt to gather information about the status of research on the Polish advertising in general and especially the socialist advertising in one place. It discusses the origins, the features and the goals of the socialist advertising based on author's research and points out possible areas of research. Source materials including 
non-serial publications, numerous archival materials and audio-visual materials. The great majority of the said materials have been investigated by the author and are used for research conducted by her on an ongoing basis.

\section{History and Essence of the Socialist Advertising}

In theory, advertising had no raison d'être in the People's Republic of Poland (PRP. The socialist market in Poland had always been dominated by manufacturers and sellers and the demand was usually much bigger than the supply. There was no major improvement in time. Repeated economic crises, rationing of goods and shortcomings of both the industry and the supply chain repeatedly caused trouble purchasing quality products and, therefore, no advertising of products or services was needed. The economic foundations of the system including priority granted to production and distribution resources ouned by the government, total exclusion of competition among manufacturers and trading companies as well as management of all production industries based on plans that apparently were neither favourable to advertising nor actually needed it. Advertising was even considered a relic of capitalism, not only unnecessary, but even dangerous for the socialist economy in 1948-1955. This view was, of course, imported directly from the Soviet Union where advertising was growing according to Lenin's assumptions as one of means of propaganda designed to create new, socialist ways of the social life $e^{1}$, until Joseph Stalin came to power. The argument that advertising activities were conducted in Western countries and in pre-war Poland only in advertiser's (manufacturer or seller) interest at consumer's expense which could not take place in the socialist economy was raised in Stalinist Poland. The adoption of that point of view resulted in the total prohibition on advertising activities in Poland abolished in mid-1950s. The Minister of Domestic Trade issued an ordinance allowing shops to have signs with unique names and not numbers used so far in 1955. "Introduction of signs with attractive names was supposed to be a technical way of underlining the unique nature of each shop which is essential to advertising campaigns" ${ }^{2}$. The importance of a pleasing package, an attractive name and the factory mark (logo) began to grow at the same time. Robotnicza Spółdzielnia Wydaunicza 'Prasa' (an editing business) began to generate 'major receipts' from commercials as soon as in $1957^{3}$. This is when the socialist advertising was born in Poland.

That particular form of advertising was defined as 'a planned activity consisting in actively providing the consumer with information using all forms and means of communication in order to cause a reasonable choice and purchase of goods and services

\footnotetext{
${ }^{1}$ N.S. Naumienko, 60 lat reklamy w Zwiazku Radzieckim, „Reklama” 1977, no. 11, p. 2-4; A. Burłajenko, Leninowski dekret o państwowym rozwoju monopolu reklamy $i$ rozwoju reklamy w okresie przejściowym: „Reklama” 1970, no. 7, p. 3-5.

${ }^{2}$ H. Kurta, Reklama prasowa: wybrane zagadnienia, Państwowe Wydawnictuo Naukowe, Warszawa 1969.

${ }^{3}$ Ibidem.
} 
consistent with the interest on the consumer and the socialist economy't in a major specialist publication of the time. It was, therefore, supposed to fulfil all the functions of capitalist advertising but it was said to be made in the interest of the society and was managed and planned at the central level. Advertising was supposed to reach many social goals including education of consumers, promotion of culture and, first of all, deployment of the socialist model of consumption in addition to economic objectives. It had many features unknown or marginal to Western advertising in order to reach these goals. It was supposed to be ideological, society-oriented, controlled, planned, accurate and true, educative, integrated, factual, comprehensive, specialized and monitored $^{5}$. J. Borouski explained the said actions as follows:

"The widespread [...] statement that the production output has to be aligned on the needs is definitely reasonable as far as the current market situation is concerned. It cannot, however, be tantamount to consumer's imposing directions of changes in the structure of consumption and, therefore, production. The assumption that a consumer is aware of their needs, i.e. that their choice is always consistent with their wishes that, in turn, are an expression of their interests, is far from being true. Too many factors usually impact the choice and hinder the understanding of one's own interest to consider 'the market voting' to be the only expression of people's needs".

This conviction was based on the assumption that the consumer was unable to define their needs or reasonably choose means and methods of satisfying them on their own. Obstacles included old customs and traditions related to both cooking and consumption in the broad sense of the word, lack of full knowledge of the range offered by the market, being influenced by people, fashion, etc. The optimum top-down consumption model and take steps shaping the demand so as to align it on the adopted model in the interest of the people themselves ${ }^{7}$. It was called the rationalization of consumption. The consumption model meant the required target consumption structures that required development and implementation of a long-term plan by the government and the consumers. Schemes related to various areas of consumptions such as housing, culture, food, etc. were supposed to be based on it. The model was a statistical construct generalized so as to include the whole country ${ }^{8}$. One more goal typical of the Polish socialist economy was poles apart from the educative actions that are long-term by their very nature. It was called securing the day-to-day market balance. It consisted in advertising only the items and services that were available at a given time and diverting people's attention from the ones that were hard to find.

\footnotetext{
${ }^{4}$ Reklama: organizacja i funkcjonowanie $w$ gospodarce socjalistycznej, red. M. Strużycki, Państwowe Wydawnictuo Ekonomiczne, Warszawa 1976.

${ }^{5}$ Ibidem.

${ }^{6}$ J. Borouski, Reklama jako czynnik ksztattowania socjalistycznej świadomości $w$ spoteczeństwie, „Reklama” 1974, no. 4, p. 1-3.

7 J. Perczak, Polska reklama prasowa w latach 1945-1989. O reklamie, której nie było?, Elipsa, Warszawa 2010

8 A. Mazur, N.M. Pazio, Reklama i propaganda $w$ realizacji modelu konsumpcji, „Reklama” 1975, no. 1, p. 3-5.
} 
This was the origin of intensive campaign promoting fish, poultry or eggs in periods of shortage of pork or beef or margarine commercials when the butter market was in crisis. Campaigns were also often conducted in order to faster sell items filling the warehouses. Such promotion was conducted e.g. in mid-1960s in order to 'sell out' the toothpaste stock ${ }^{9}$. Attempts to sell obsolete or defective goods in this way were frequent. This is why the conviction that a product too strongly advertised must have been 'trash' as good things did not need advertising was widespread among socialist consumers. All that was the source of the conviction that the Polish post-war advertising began to develop only after 1989 which is still prevailing. My research is designed to, among other things, debunk this false, but still widespread opinion. Admittedly, the socialist advertising was significantly different from what is considered to be advertising today, it included many elements of propaganda, was actually subordinated to it and was 'relieved' from commercial goals to a large extent, but it cannot be said that there was no advertising in socialist Poland. On the contrary, it existed and was developing. Moreover, the complicated history of politics and economy in the PPR made it a diversified and interesting phenomenon decidedly worth being researched on in depth.

\section{Status of Research}

The literature concerning various aspects of advertising is very rich. There are publications discussing the history of the Polish advertising in various periods including texts on advertisements for publishing houses and bookstores in the 18th century by Danuta Hombek ${ }^{10}$ and analyses of press advertisements for books In the 18th century by the above-mentioned author and Stanisław Grzeszczuk ${ }^{11}$. A study on the consumer advertising in the 19th century has been published by Agnieszka Janiak-Jasińska ${ }^{12}$, while press commercials of the interwar period are discussed by Adam Bania ${ }^{13}$. The article by Zbigniew Bajka discussing the history of advertising from its very

\footnotetext{
9 J. Perczak, op. cit.

${ }^{10}$ D. Hombek, Reklama wydawnicza i księgarska w „Gazecie Warszawskiej” w latach 1764 1795, Wyższa Szkoła Pedagogiczna im. Jana Kochanouskiego, Kielce 1988; Wydawnictwa warszawskie Tadeusza Podleckiego w świetle publikacji reklamowych z lat 1785-1794, Wyższa Szkoła Pedagogiczna im. Jana Kochanowskiego, Kielce 1997.

11 D. Hombek, S. Grzeszczuk, Książka polska w ogłoszeniach prasowych XVIII wieku: źródła, vol. 1, „Wiedza o kulturze”, Wrocław 1992; Ksiązka polska w ogłoszeniach prasowych XVIII wieku: źródła, vol. 2, „Universitas”, Kraków 1992; Książka polska w ogłoszeniach prasowych XVIII wieku: źródta, vol. 3, „Universitas”, Kraków 1992; Książka polska w ogłoszeniach prasowych XVIII wieku: źródła, vol. 4., „Universitas”, Kraków 2000; Książka polska w ogłoszeniach prasowych XVIII wieku: źródta, vol. 6, „Universitas”, Kraków 2016.

12 A. Janiak-Jasińska, Aby wpadto w oko...: o reklamie handlowej w Królestwie Polskim na podstawie ogłoszeń prasowych, DiG, Warszawa 1998.

${ }_{13}$ Polska reklama prasowa 1930-1939, Wydawnictwo Naukowe DWN, Warszawa 1995.
} 
beginning in a cross-sectional manner is also worth noting ${ }^{14}$. An issue of "Zeszyty Prasoznawcze" devoted to advertising and containing the above-mentioned article by Z. Bajka along with a comparative analysis of the advertising vocabulary in the PRP and the early period of the free market system in Poland appeared in $1993^{15}$. Jerzy Bralczyk ${ }^{16}$ also used to analyse the language of advertisements.

Other than the above-mentioned article by W. Pisarek papers on advertising in socialist Poland are, however, not numerous. Such absence may be a result of conviction that such activity did not exist in the PRP or wrong equation of advertising with propaganda. Even if publications refer to the advertising of that period, such references are short and general in nature; no attempt to analyse the topic in depth is made. The paper by J. Perczak: Polska reklama prasowa w latach 1945-1989. O reklamie, której nie byto? ${ }^{17}$ was the first book wholly dedicated to the advertising in the PRP. It mainly focuses on press advertising that has been analyzed in most detail. Since, however, it was the first paper dedicated to the topic after the change of the political system, it also outlines the history of the socialist advertising, the environment in which it was developing, its managing bodies, issues related to education and specialized publications. It also includes a review and a description of major media and forms of advertising. The said paper does not, however, exhaust the subject due to its nature and the huge amount of materials still to be researched on. The socialist advertising is sometimes marginally brought up in general papers concerning advertising or the history of media.

Texts on the advertising in the PRP published after 1989 also include articles by J. Perczak (2002, p. 131-148, 2003, p. 133-163, 2010, p. 127-142) and Renata Piasecka (2001, p. 93-39).

\section{Sources}

Research on the PRP advertising is facilitated by the big amount of various sources starting from archival ones through printed ones (specialized literature and magazines as well as memories) to numerous examples of PRP advertising. Contrary to appearances, there are many sources and papers of that period, i.e. 1945-1989. Archival sources stored in the Archive of New Files in Warsaw are considered to be the most important. The file entitled Rada Programowa Reklamy being a part of the Ministerstwo Handlu Wewnętrznego cluster is probably the largest and the most varied one. It is a very rich cluster including information about the development and activities of advertising authorities and bodies organizing the advertising in the PRP. Information about the setup

${ }_{14}$ Z. Bajka, Krótka historia reklamy na świecie i $w$ Polsce, „Zeszyty Prasoznawcze” 1993, no. $3 / 4$, p. $16-47$.

${ }^{15}$ W. Pisarek, Stowa na ustugach reklamy w Polsce (1962-1993), „Zeszyty Prasoznaucze” 1993, no. 3/4, p. 65-77.

${ }^{16}$ J. Bralczyk, Język na sprzedaż, „Business Press”, Warszawa 1998.

17 J. Perczak, Polska reklama prasowa w latach 1945-1989, op. cit. 
of and changes in the Advertising Board of the Ministry of Domestic Trade as well as its policies and regulations covering topics from organization of advertising campaigns and shop window or slogan competitions through publications (advertising catalogues) to organization of schools of advertising in Poland can be found in it. It is a source of knowledge of conditions and rules of promotional activities in Poland, decision makers and obstacles encountered. Information about setup of state-ouned advertising enterprises or names of people involved in the promotional business in various PRP bodies can also be found there. Texts on ways of conducting activities concerning the 'securing of day-to-day market balance' mentioned above or plans of product placement in various media are included, too. The way of implementing those plans can also be discovered during the analysis of the media content. Drawbacks of the cluster include absolute disorder and absence of detailed descriptions of the files making research difficult.

Files of the Ministry of Foreign Trade including information about Przedsiębiorstwo Handlu Zagranicznego Agpol dealing with advertising in international markets are also a source of abundant knowledge. Just like the cluster mentioned earlier, they include wealth of information not only about Agpol itself, but also about ways of and conditions for advertising Polish products abroad. Specifications of costs of promotion covered by each foreign trade centre by type of promotion are another advantage of the cluster. 'Przedsiębiorstuo Usług Reklamowych „Reklama” w Warszawie' including documents concerning one of the largest enterprises dealing with advertising in the broad sense of the word country-wide and attached to the Ministry of Domestic Trade in 1956-1970 is another very interesting cluster. Data of the business conducted by its successor, namely, Państwowa Agencja Reklamowa 'Reklama', are included in the Państwowa Agencja Reklamowa „Reklama” 1971-2004 cluster. Both clusters include information about the setup of the agencies, their gradual geographic expansion, memorandums of association, objectives, activities and liquidation. Files include details such as safety requirements applicable to the installation of neon signs, detailed lists of prices of various light advertisements, information about activities of field offices or publication of Reklama - a professional monthly - including list of fees for authors of texts and many other data The exact history of both bodies can be restored based on those two clusters. Please note that Państwowa Agencja Reklamowa 'Reklama' was finally wound up only in 2004. Those clusters are among the best preserved ones concerning the PRP advertising.

Files of Robotnicza Spółdzielnia Wydawnicza Prasa-Książka-Ruch cannot be considered to be well preserved. They also had an advertising agency on their own called 'Pouszechna Agencja Reklamowa'. As the leader of the PRP press market they were also leading the press advertising market. Tracking back the history of that area of their business would therefore be very interesting.

The files of the Supreme Chamber of Control also include many interesting data. They mainly concern foreign trade advertising. Files of the Political Bureau of the Central Committee of the Polish United Workers' Party could also be a valuable source. 
As directions of the economic policy and, therefore, centrally managed advertising were defined at such a high level, decisions concerning directions of advertising campaigns conducted at home and abroad as well as choices of goods that could be advertised in specific periods and those that should not be promoted due to e.g. poor supply can be found in those files. Further insights into legacy PRP archives will undoubtedly result in more knowledge of the advertising activities in the PRP although it can be stated with certainty that clusters of files stored in the Archive of New Files that are essential for the topic in question have already been made available.

The archive of files of TVP SA is another valuable cluster. The files stored there make tracking the history of TV advertising back to the emergence of the television possible. They include documents concerning setup and activity of advertising departments of the television, the advertising policy of the Radio Committee, relationships with other bodies such as the Advertising Board, financial plans, advertising regulations, contracts, letters, reports and many other items.

The 'Reklama' monthly, the best and the most important industrial magazine published without interruption from 1968 to 1990 by Przedsiębiorstwo Usług Reklamourych 'Reklama' (subsequently named Państwowa Agencja Reklamowa 'Reklama'), is another source of information. It included many specialized articles on various aspects of advertising by Polish authors or translated from foreign languages. Publications included texts on the history of advertising, practical tips concerning e.g. shop windous as well as articles on shortcomings and issues of the Polish advertising industry. Intervieus with advertising workers and decision makers were also published. 'Reklama' is a valuable addition to archival resources.

Non-serial socialist publications from the PRP period should be considered sources, too. Specialized and scientific literature on advertising was also abundant. Admittedly, there is no work covering the entire history or theory of the socialist advertising, but there are a few dozen various titles from the 1946-1989 period presenting the issue in a general manner or from a selected perspective. The said works cover both national and international advertising, the position of advertising in the marketing system and in various media, rules of promotion of various groups of goods, market and advertising efficiency research, legal rules of advertising in Poland, various forms of advertising, its position and role among other marketing activities, etc. They include guides for advertising workers, manuals for various levels of studies and translations of foreign language works proving that the PRP theory of advertising was copiously profiting from models provided by more experienced countries, both socialist and capitalist. The relatively easy access to the majority of those materials is essential. Collections of smaller libraries were deprived of many useful titles including those relating to advertising, but almost all of them have been preserved by the National Library. Some of those books appear in second-hand bookshops or at on-line auctions. The selection of literature among those rich resources is, therefore, not too difficult. Books deserving particular attention include, among other things, works by Marian 
Strużycki ${ }^{18}$ and Tadeusz Sztucki ${ }^{19}$ on general issues of theory of socialist advertising and various forms and means of advertising and by Mirosław Brzostouski ${ }^{20}$, Henryk Kurta $^{21}$ and Zbigniew Zauidzki ${ }^{22}$ on press advertising. A collection of legal acts regulating the advertising in the PRP has been presented by Bronisław Słotwiński ${ }^{23}$. This does not mean, of course, that other publications are less valuable. They are certainly valuable supplementary materials for those researching on the socialist advertising from selected perspectives (selected bibliography is provided at the end of this article).

The use of memoirs is less easy. There is a kind of trend towards memoirs from the PRP period, but their authors do not usually dedicate any space to advertising. No mentions of advertisements or audience's reactions to them have been found in memoirs by, among others, Jeremi Przybora, Maryla Rodowicz, Zofia Kucówna, Loda Halama, Hanka Bielicka and Beata Tyszkiewicz. A few mentions can only be found in Joanna Chmieleuska's autobiography. Some information about popularity of commercials in the PRP cam be sourced from Polish films, e.g. Hydrozagadka by Andrzej Kondratiuk (released in 1970) where characters talk to one another using advertising slogans. Other films also include clues of popularity of advertisements as well as product placement by the government. Several episodes of 07 zgłoś się TV series (1976-1987, directed by Krzysztof Szmagier) include clear placement of Polish Airlines LOT; Matżeństwo z rozsądku, a comedy by Stanisław Bareja (released in 1966), advertises vacations in the Mazury lake district and consumer credits financed by ORS; Nie lubię poniedziatku, a comedy, encourages viewers to play Toto Lotek (the national lottery) in a funny way and its characters conduct a funny erotic dialog using the most common Polish scent brand names.

Commercials themselves are another valuable resource. The short time distance is the reason behind the unusual wealth and variety of press advertisements, but also all other forms and media. The vogue for collecting PRP commercials contributes to their rising prices, but on the other hand, there are many of them in the auction and second-hand market. Please note that the great majority of the current forms of advertising were known and used in the PRP. The ones that emerged as the technology developed, e.g. computer commercials, were the only ones that did not exist

${ }_{18}$ See e.g. Reklama. Organizacja i funkcjonowanie $w$ gospodarce socjalistycznej, ed. M. Strużycki, Warszawa, Państuowe Wydawnictuo Ekonomiczne, Warszawa 1976.

${ }_{19}$ See e.g. T. Sztucki, Miejsce i funkcje reklamy w zespole elementów aktywizacji sprzedaży, Warszawa 1969; Zagadnienia skutecznej reklamy, Touarzystuo Naukoue Organizacji i Kierounictua, Warszawa 1965.

${ }^{20}$ See e.g. M. Brzostouski, Język reklamy prasowej, Polskie Touarzystwo Ekonomiczne, Warszawa 1975; Teoretyczne podstawy reklamy prasowej, IHWiU, Warszawa 1976.

${ }^{21}$ See e.g. H. Kurta, Reklama prasowa: wybrane zagadnienia, Państwowe Wydawnictuo Naukowe, Warszawa 1969; Rola i znaczenie reklamy w środkach informacji masowej. Skrypt dla studentów Studium Dziennikarskiego UW, Wydawnictua Uniwersytetu Warszauskiego, Warszawa 1965.

${ }^{22}$ Z. Zawidzki, Reklama prasowa, Polskie Towarzystuo Ekonomiczne. Stowarzyszenie Wyższej Użyteczności. Dyrekcja Szkolenia Ekonomicznego, Warszawa 1974.

${ }_{23}$ B. Słotwiński, Prawo o reklamie: omówienie i zbiór przepisów, „Reklama”, Warszawa 1967. 
at that time. Outdoor advertising including neon signs, signboards, murals, posters, shop windows, etc. was well developed and so were all kinds of visual advertising (flyers, distance sale catalogues, brochures, flexi disc advertising, etc.), various kinds of cinema, radio and TV commercials, advertising gadgets and gifts or advertising shopping bags. The analysis of the contents and forms of those advertisements could also be a valuable contribution to the research on the issue.

\section{Research Outlooks}

The wealth and the variety of sources as well as the small degree of their use so far provide researchers with immense opportunities. Advertising is complex and multidisciplinary; this paper presents, however, opportunities to research on the entire socialist advertising system from the perspective of George Laswell's communication model. It is transparent and allows presentation of all the opportunities provided by the analysis of the PRP advertising.

\section{Who Is Speaking?}

This includes many issues related to the organization and management of advertising. Who was broadcasting the commercial? Who was choosing the advertised object and the time of advertising? Were all the decisions made at the central level or were individual industry associations, factories or trade centres allowed to make decisions or provide advice in the area of advertising of their products? What was the usual pattern of relationships between manufacturers, resellers and advertising authorities? Who was organizing the advertising activities - the ministry, factories or resellers? Where was advertising staff trained and how was secondary and university education in the area developing? What was the approach to advertising in each period of the PRP? The promotion management structure from the Central Committee of the Polish United Workers' Party (CC PUWP) through ministries to individual factories as well as the structure, powers and rules underlying the relationships of all institutions dealing with advertising should be tracked down. Tracking down the policy implemented by CC PUWP seems particularly important. Tracking down the activities of advertising agencies and their relationships with manufacturers as well as each advertising board attached to a ministry or transversal should also be retraced. The findings made so far have been published in a book by J. Perczak, but there is still much to be done. Such research is essential for the history of the PRP economy, all the more so because the approach of the government to advertising was different in each period of the PRP history (1945-1948, 1949-1955, 1956-1970, 1971-1980, 1981-1989).

\section{What Is Said?}

Essential goals include showing the preferences of the government as far as advertising specific goods was concerned changing over time. This was due to the specific objectives 
of the Polish advertising industry, namely, muffling the demand for goods unavailable from the market at a given time and strongly promoting replacement or luxury goods. Pointing out what could be promoted in each decade and what could not and why would therefore be very interesting and useful. Other goals of the advertising industry at that time included the so-called building of the socialist model of consumption which objective was convergent with the above-mentioned market regulation objective. The building process consisted in conducting activities that could be divided into two groups. The first included implementation of the relevant price, income, production and sale organization policy by the government in conformity with the underlying social and economic plan. The second group of activities included structuring of consumers' preferences through propaganda and advertising. Those activities were conducted in the best interest of citizens and were designed to change consumption-related habits and traditions as the government wished ${ }^{24}$. Research on manners of shaping the said pattern using advertising will contribute to the history of Polish economic crises and the social policy implemented by the PUWP. All the goals of the socialist advertising accessory to those already mentioned including in particular educational, upbringing, culture promoting and, of course, information-related goals need to be described. Those objectives were specific to the socialist advertising. The first, educational, was supposed to shape the market and to implement the socialist pattern of consumption. The government arbitrarily decided that customers were unable to make reasonable purchasing choices on their own as they were guided by snobbery, fashion, etc. rather than reason, quality of goods or actual needs which was detrimental to both individuals and the entire society. The above assumption underlay the socialist consumption pattern. Consumers were educated not only through advertising; organisms such as Samopomoc Chtopska or Praktyczna Pani also contributed to that education. It was supposed to affect people so as to teach them how to make reasonable choices and how to use products. This entailed multiple long-term educational activities including all phases of consumer's actions from selecting a consumption pattern through its implementation by means of purchase of goods or services to using the goods purchased at home ${ }^{25}$. It helped the customer to get to know the market range at the time of purchase designed to meet predefined needs, broke distrust or aversion to new products or their improved makes and, as a result, provided them with knowledge of the market and helped to develop consumption and raise its level through customer's use of latest scientific and technological achievements.

Advertisements were also expected to be helpful in the phase of use of goods at home. Relevant information was a necessary condition for proper use of the purchased products including both manufactured goods (clothes, household appliances, cosmetics, furniture, etc.) and food. Such information was expected to be provided at e.g. shous of use of household appliances, tasting dishes made from advertised

${ }^{24}$ J. Borouski: Reklama jako czynnik kształtowania socjalistycznej..., op. cit.

25 B. Modzelewska, Edukacja konsumenta - jej rola w ksztattowaniu struktury konsumpcji, „Reklama” 1979, no. 9, p. 2-3. 
products, proposing recipes, etc. Clothes cleaning directions or user's manuals provided by manufacturer were also supposed to be educative. All that was designed to make customers get acquainted with the goods and encourage them to buy them and use them safely and efficiently. Education should be continuous due to technological development, nutrition research and changing fashion trends. Advertising was supposed to bring up everybody involved in the production and distribution chain including manufacturers, sellers and individual customers in addition to educating them. Its goals included enhancing the consumption culture as well as service culture and neatness as even the best advertisement was inefficient if the staff was rude and reluctant to provide advice or assistance, the shop was scruffy or goods were poorly displayed; shaping good taste and sensitiveness to beauty and technological progress; stimulating imagination; teaching everyday economical behaviours, etc.

Promoting culture was another objective of advertising. This was achieved by means of, among other things, educational contents designed to change habits and preferences. Advertising contributed to the promotion of culture by raising the level of consumption through channelling interest to non-material goods. The required good artistic and aesthetic quality of advertisements, use of proper Polish including no swear words and prohibition on some publicity stunts also had effect on the level of culture of the audience's everyday life.

The research on advertising will therefore contribute a lot to the knowledge of history of everyday life culture as well as tastes and habits related to aesthetics, clothes, food, culture, etc. and, therefore, important social changes caused by, among other things, advertising activities. The fact that the post-war Polish society was affected by huge transformations is also important as mass migration of countryside people to cities resulting in a change in ways of life (work in specific hours and more spare time), general availability of education and culture including high culture and increased availability of civilizational achievements resulted in educational, culture-making or upbringing goals of advertising being as important as economic ones.

\section{Who Is The Target?}

Research on the target audience is undoubtedly of importance for many sciences. The essential questions to be asked are: a) were there more advertisements addressed to institutions or individuals? b) which sex was more often targeted by advertisements designed for individuals? c) which products were recommended to women and which one were recommended to men? d) were children targeted? e) which products were recommended to children and teenagers? f) were target groups determined as precisely as today or were the most general criteria sufficient? This will be (at least partial) an answer to e.g. questions about social clichés in the PRP or economic issues such as relationships between specific sectors including industry, wholesale and retail. Advertising was extremely centralized in the PRP. No business was allowed to carry out promotion on its own whether in Poland or - all the more so - abroad. The industry 
was obliged to address commercial notices to wholesalers that, in turn, notified retailers who were eventually disclosing them to customers ${ }^{26}$.

\section{What Are The Media?}

Media used by the socialist advertising are a huge group of research issues. Firstly, the advertisements appearing in all the media of that time should be considered. Researchers will face, among other things, the following issues: the advertising policy of RSW in various periods of the PRP, advertisements in country-uide and regional newspapers and magazines of various kinds including the interesting issue of the promotional activity of the official Party newspapers) and the co-operation between the press and bodies organizing country-wide advertising campaigns. This is also the direction of the research on TV and radio commercials. The standpoint of the Radio Committee on advertising as well as the political and economic environment of the promotional activity of the said media are of importance. This is evidenced by e.g. expenses on the Radio - Tele - Reklama office and its successors, quantity of services provided and amounts earned. The variety of forms of advertising in both radio and TV is equally important. The latter even used product placement ${ }^{27}$. All that information is included in the records of TVP.

Shop windows were among essential advertising media in the PRP. The government was strongly backing up this way of encouraging customers to buy because a large group of people was reached without big expenses or occupying the space in newspapers or magazines. This is how Alfred Jaroszewicz explained the exceptional place of advertising in shop windows:

"[...] shop windows attract the attention of pedestrians who are prospective buyers of goods and services and raise interest in the goods that the shop is offering and that it wants to make customers buy. The decision to buy a product or service matures in front of the shop window. A person rarely leaves a shop without buying anything once they enter the outlet. That psychological phenomenon of maturing of a decision is even more pronounced in front of windows of shops using modern forms of selling [...]. The windows of such shops not only approach goods to buyer's eyes, but also associate them with an actual need and pedestrian's financial capacity therefore making a quick choice and the decision to buy easier to them" ${ }^{28}$.

Shop windous were considered to be a street design item; therefore, they were often decorated in an artistic manner and the specialized literature and magazines devoted much space to the theory of arranging exhibitions. Country-wide shop window contests were organized and the "Reklama" monthly published articles on issues connected with the proper decoration of shop windows on a regular basis. Antoni Kowalski

\footnotetext{
${ }^{26}$ System reklamy na rynku wewnętrznym, „Reklama” 1973, nr 8, s. 1-3.

${ }^{27}$ W. Naumouski, Reklama audiowizualna, Polskie Towarzystwo Ekonomiczne, Warszawa 1974, s. 20.

${ }^{28}$ A. Jaroszewicz: Z warsztatu Rady Programowej Reklamy [in:] Z doświadczeń reklamy w Polsce, Agencja Wydawnicza „Ruch”, Warszawa 1964.
} 
distinguished as much as 6 various shop window decorating methods according to proportions of goods, decorative items and auxiliary devices ${ }^{29}$.

Popular media also included advertising posters that were not limited to theater or cinema announcements. Many businesses such as Cora, Telimena or Orbis were using posters for advertising. This part of the issue makes us enter the domain of history of art as authors of advertising posters included the most outstanding members of the Polish Poster School, namely, Waldemar Świerzy, Jan Młodożeniec, Janusz Grabiański and many others. This form of advertising was often criticized, mainly because of quality ${ }^{30}$, preponderance of art over advertising and the visibly poorer quality of the latter ${ }^{31}$, but there were also cases of highly appreciative appraisals ${ }^{32}$. "The Polish utilitarian graphics is a world-wide leader in terms of both artistic and advertising value, posters being one of its most powerful media", industry magazines wrote at the occasion of publication of a thesis in German on Polish posters ${ }^{33}$. There are no books devoted mainly to advertising posters in the PRP, but the rich collection of the Poster Museum in Wilanów is an excellent basis for research.

Research could also focus on neon signs - another advertising medium preferred by the government - other outside advertising media or advertising publications. The latter included unusual items such as flexi discs, but also numerous leaflets, many kinds of brochures or mail-order selling catalogs of a very decent editorial quality.

Media such as packaging materials or labels, the quality of which was of great importance to the advertising bodies, deserve a separate paper. Some of them were really beautiful and solid. They often were a reference to the then-current artistic trends. Examples include packaging of chocolate products of major Polish brands including 22 Lipca (E. Wedel), Goplana, Wawel or Olza, tin boxes (tea or sweets boxes), scent bottles or Nivea product packaging always featuring the same colours and font. Research on packaging will contribute to, among other things, the history of aesthetics and economy as every crisis caused replacement of beautiful packaging and labels with so-called replacement packaging usually made of waste materials, drab and ugly.

Advertising gifts were also known and widely used in the PRP. Admittedly, their production was encountering many organizational obstacles such as lack of materials and capacity, poor workmanship, many bureaucratic obstacles to obtaining approval of production, etc., but businesses in the PRP were offering a wide variety of so-called advertising gadgets. Pennants seem to have been the most popular, but we also have to do with key rings, document files, lighters, ashtrays, table linen (table cloths and napkins), commemorative plates, wallets, paper knives, shopping bags, paper clips

\footnotetext{
${ }^{29}$ A. Kowalski, Reklama, Wydawnictua Szkolne i Pedagogiczne, Warszawa 1985.

${ }^{30}$ Polski plakat $w$ reklamie eksportu, „Reklama w handlu zagranicznym, Rynki Zagraniczne” insert, no. 4, p. 45.

31 J. Cieślak, Plakat imprezowy, „Reklama w handlu zagranicznym 1967, Rynki Zagraniczne” insert, no. 2, p. 25-28.

32 Konkursy daja efekty, „Reklama w handlu zagranicznym 1963, Rynki Zagraniczne” insert, no. 6, p. 25.

33 „Reklama w handlu zagranicznym 1963, Rynki Zagraniczne” insert, no. 7, p. 8.
} 
and many other ${ }^{34}$. As mentioned above, there are currently no kinds of advertising that did not exist in the PRP except for those resulting from the technological development. The area to be researched is therefore vast and the material is exceptionally abundant.

Another class of issues includes communication between the advertiser and the audience as well as verbal and non-verbal means of communication used in advertising. Socialist advertisers were bound by some linguistic, ethical and technological limitations. The first consisted in the obligation to use beautiful Polish with no bad language; the second included e.g. the prohibition on making reference to emotions, especially base ones (causing jealousy or complexes, or suggesting that ouning things makes one better than others). The latter mainly included poor quality of paper and print, great problems with the manufacturing of quality advertising gadgets, many obstacles to production and broadcasting of commercial spots and many others. The research on the structure of advertisements is nevertheless very interesting. Possible areas to be analysed include e.g. argumentation (rational or emotional, making reference to the choice, the functioning of the product, customer's needs, etc.), references made to cultural, literary or other themes and symbols, use of humor, way of addressing the target group, slogans or words used the most frequently. The latter issue were researched on by W. Pisarek. Non-verbal means of influence deserving particular attention include illustrations that sometimes played the main role, trademarks, colours and movement. The effect of fashions and styles in art on the visual advertising is another interesting issue.

\section{What Is The Effect?}

This question is undoubtedly the most difficult to answer. Some documents of the Supreme Chamber of Control include information about the efficiency of commercial advertisements, but only foreign markets are concerned. As far as the domestic market is concerned, some data can be found in the records of the Political Bureau of the Central Committee of the Polish United Workers' Party, Advertising Board or documents left after the liquidation of various factories. Some indirect conclusions could perhaps be drawn from the press of that time, but the results of such research would probably not provide any accurate answer to the question about the efficiency of specific campaigns.

The research on the history of the socialist advertising is an indispensable part of research on the PRP culture in the broad sense of the word including the research on the political and marketing communication. It will provide historians of economy and culture, psychologists, social scientists, media scientists and social communication experts with interesting materials. The vast and diversified field of research is a source of interesting and important information for specialists in many domains. The large

${ }_{34}$ Judyta Perczak's personal collection of socialist advertising items includes many gadgets of this kind. 
amount of archival, printed, graphic and audio-visual sources is also an important factor. Failure to profit from this wealth would be a major mistake.

\section{A Selection of Publications on Advertising from the 1945-1989 Period}

Białecki Klemens, Marketing $w$ gospodarce socjalistycznej, Warszawa 1978.

Białecki Klemens, Polityka reklamowa w eksporcie, Warszawa 1966.

Brzostowki Mirosław, Reklama prasowa, Warszawa 1976.

Brzostowki Mirosław, Szymczak Jadwiga, Działalność promocyjna jednostek gospodarczych $w$ Polsce, Warszawa 1978.

Brzostowki Mirosław, Teoretyczne podstawy reklamy prasowej, Warszawa 1976.

Elgozy Georges, Paradoksy reklamy, perswazja legalna, Warszawa 1973.

Górkowa Maria, Zasady reklamy prasowej i ogłoszenia reklamowe, Warszawa 1965/1966.

Górniak Stefan, Ehrlich Emil, Obstuga klienta w sklepie detalicznym, Wrocław, Warszawa 1948.

Jastrzębouski Wacław, Reklama handlowa: poradnik, Warszawa 1956.

Koprowicz Janusz, Krakowiak Stanisław, Reklamy świetlne jarzeniowe, Warszawa 1971.

Kowalski Antoni, Reklama, Warszawa 1985.

Kurta Henryk, Reklama prasowa (wybrane zagadnienia), Warszawa 1969.

Międzynarodowy kodeks reklamy, Warszawa 1968.

Naumouski Wiesław, Reklama radiowa i telewizyjna, Warszawa 1967.

Reklama w działalności marketingowej, Warszawa 1997.

Reklama: organizacja i funkcjonowanie $w$ gospodarce socjalistycznej: praca zbiorowa, red.

M. Strużycki, Warszawa 1976.

Rojeuski Tadeusz, Wyposażenie pracowni reklamy. Poradnik dla nauczycieli szkół handlowych, Warszawa 1960.

Słotwiński Bronisław, Prawo o reklamie. Omówienie i zbiór przepisów, Warszawa 1967.

Sztucki Tadeusz, Badanie skuteczności reklamy, Warszawa 1970.

Sztucki Tadeusz, Formy i środki aktywizacji sprzedaży, Warszawa 1966.

Sztucki Tadeusz, Zagadnienia skutecznej reklamy, Warszawa 1965.

Szymczak Jadwiga, Formy promocji sprzedaży, Warszawa 1977.

Świstun Konstanty, Ogłoszenia prasowe w intensyfikacji sprzedaży, Warszawa 1972.

Wojeński Jan, Szyldy i reklamy sklepowe, Warszawa 1969.

Z doświadczeń reklamy w Polsce, Warszawa 1964.

Zawidzki Zbigniew, Reklama prasowa, Warszawa 1974.

\section{References}

Bajka Z., Historia mediów, Wydawnictwo i Drukarnia Touarzystua Słowaków u Polsce, Kraków 2008.

Bajka Z., Krótka historia reklamy na świecie i w Polsce, „Zeszyty Prasoznawcze” 1993, no. 3/4, p. $16-47$.

Borouski J., Reklama jako czynnik kształtowania socjalistycznej świadomości w społeczeństwie, „Reklama” 1974, no. 4, p. 1-3.

Bralczyk J., Język na sprzedaż, Business Press, Warszawa 1998. 
Burłajenko A., Leninowski dekret o państwowym rozwoju monopolu reklamy i rozwoju reklamy $w$ okresie przejściowym, „Reklama” 1970, no. 7, p. 3-5.

Cieślak J., Plakat imprezowy. „Reklama w Handlu Zagranicznym (insert), Rynki Zagraniczne” 1967, no. 2, p. 25-28.

Hombek D., Reklama wydawnicza i księgarska w „Gazecie Warszawskiej” w latach 1764-1795, Wyższa Szkoła Pedagogiczna im. Jana Kochanouskiego, Kielce 1988.

Hombek D., Wydawnictwa warszawskie Tadeusza Podleckiego w świetle publikacji reklamowych z lat 1785-1794, Wyższa Szkoła Pedagogiczna im. Jana Kochanouskiego, Kielce 1997.

Hombek D., Grzeszczuk S., Książka polska w ogłoszeniach prasowych XVIII wieku: źródła, vol. 1. „Wiedza o Kulturze”, Wrocław 1992.

Hombek D., Grzeszczuk S., Ksiązka polska w ogłoszeniach prasowych XVIII wieku: źródła, vol. 2., „Universitas”, Kraków 1992.

Hombek D., Grzeszczuk S., Książa polska w ogłoszeniach prasowych XVIII wieku: źródła, vol. 3. „Universitas”, Kraków 1992.

Hombek D., Grzeszczuk S., Książka polska w ogłoszeniach prasowych XVIII wieku: źródła, vol. 4., „Universitas”, Kraków 2000.

Hombek D., Grzeszczuk S., Książka polska w ogłoszeniach prasowych XVIII wieku: źródła, vol. 6, „Universitas”, Kraków 2016.

Janiak-Jasińska A., Aby wpadto w oko...: o reklamie handlowej w Królestwie Polskim na podstawie ogłoszeń prasowych, DiG, Warszawa 1998.

Jaroszewicz A., Z warsztatu Rady Programowej Reklamy [in:] Z doświadczeń reklamy w Polsce, Agencja Wydawnicza „Ruch”, Warszawa 1964.

Konkursy daja efekty, „Reklama w handlu zagranicznym (insert). Rynki Zagraniczne” 1963, no. 6, p. 25.

Kowalski A., Reklama, Wydawnictua Szkolne i Pedagogiczne, Warszawa 1985.

Kurta H., Reklama prasowa: wybrane zagadnienia, Państwowe Wydawnictuo Naukowe, Warszawa, 1969.

Kurta H., Rola i znaczenie reklamy $w$ środkach informacji masowej. Skrypt dla studentów Studium Dziennikarskiego UW, Warszawa, Wydawnictwa Uniwersytetu Warszawskiego, 1965.

Mazur A., Pazio M.N., Reklama i propaganda $w$ realizacji modelu konsumpcji, „Reklama”, 1975, no. 1, p. 3-5.

Modzeleuska B., Edukacja konsumenta - jej rola w ksztattowaniu struktury konsumpcji, „Reklama” 1979, no. 9, p. 2-3.

Naumienko N.S. (1977), 60 lat reklamy w Zwiąku Radzieckim, „Reklama”, no. 11, p. 2-4.

Naumouski W., Reklama audiowizualna, Polskie Towarzystwo Ekonomiczne, Warszawa 1974.

Perczak J., Formy reklamy socjalistycznej, „Studia Bibliologiczne Akademii Śuiętokrzyskiej” 2003, no. 7, p. 133-163.

Perczak J., Polska reklama prasowa w latach 1945-1989. O reklamie, której nie było?, Warszawa, „Elipsa” 2010.

Perczak J., Polska reklama socjalistyczna - zarys problemu, „Studia Kieleckie Seria Bibliologiczno-Prasoznawcza" 2002, no. 2, p. 131-148.

Perczak J., Reklama w PRL: kto, komu i po co oferowat towary w Polsce Ludowej? [in:] G. Miernik (ed.), Kultura wysoka, kultura popularna, kultura codzienności $w$ Polsce 1944-1989, Kielce, Uniwersytet Humanistyczno-Przyrodniczy Jana Kochanouskiego w Kielcach 2010, p. 127-142. 
Judyta Ewa Perczak

Piasecka R., Działalność Biura Ogłoszeń i Reklam Polskiej Agencji Prasowej w latach 1945-1948, „Zeszyty Prasoznaucze” 2001, no.1/2, p. 93-99.

Pisarek Walery, Stowa na ustugach reklamy w Polsce (1962-1993), „Zeszyty Prasoznawcze”, 1993, no. 3/4, p. 65-77.

Polska reklama prasowa 1930-1939, Wydawnictwo Naukowe DWN, Warszawa 1995.

Polski plakat $w$ reklamie eksportu, „Reklama w handlu zagranicznym”, wkładka „Rynki Zagraniczne", No 4, p. 45.

Reklama: organizacja i funkcjonowanie $w$ gospodarce socjalistycznej, ed. M. Strużycki, Państwoue Wydawnictwo Ekonomiczne, Warszawa 1976.

Reklama w handlu zagranicznym, „Rynki Zagraniczne” (insert), 1963, no. 7, p. 8.

Strużycki M., Reklama, konsumpcja, rynek - podstawowe sprzężenia, „Reklama” 1975, no. 10, p. $1-3$.

System reklamy na rynku wewnętrznym, „Reklama” 1973, no. 8, p. 1-3. 